POLSKA AKADEMIA UMIEJĘTNOŚCI

ANNA WoźNIAK

Katolicki Uniwersytet Lubelski Jana Pawła II

\title{
KULTURA MASOWA W ROSYJSKIEJ MYŚLI TEORETYCZNEJ. OD FORMALIZMU DO SEMIOTYKI
}

\author{
MASS CULTURE IN RUSSIAN THEORETICAL REFLECTION: \\ FROM FORMALISM TO SEMIOTICS
}

\begin{abstract}
Streszczenie
Kultura masowa pojawiła się w latach dwudziestych XX w. jako przedmiot badań formalistów rosyjskich, którzy rozpoczęli dyskusję na temat jej specyfiki i wyznaczników. W artykule rozważane są prekursorskie teoretyczne ustalenia na temat kultury masowej: Borysa Eichenbauma, Jurija Tynianowa i Wiktora Szkłowskiego, którzy badając kulturę/literaturę niską, koncentrowali się na kwestiach dzieła literackiego oraz autora-twórcy, pojmowanych w kontekście społecznym, mówili o dynamizmie, ewolucji, rozwoju i zamienności/wymienialności zjawisk literackich, a także systemowości i funkcjonalności szeregów kulturowych. Istotny był także namysł formalistów nad kinematografią i wypracowanie teorii o estetyce kina. W artykule ukazuje się również dokonania Jurija Łotmana, semiotyka i kulturologa, który czerpiąc z inspiracji formalistycznej, poszerzył znacznie opis i rozumienie kultury masowej, między innymi o aspekt teorii informacji. Łotmanowski model systemu literackiego ujmował semiotykę zjawisk kulturowych, pogranicznych i niesystemowych, wypierających elementy kultury oficjalnej. W rozważaniach mowa jest również o problemie wartościowania kultury masowej.
\end{abstract}

\section{Summary}

Mass culture became a subject of investigation for the Russian formalists in the 1920, who started a debate on the nature and the exponents of this phenomenon. In the article is considered the theory of mass culture Boris Eikhenbaum, Yuri Tynyanov and Viktor Shklovsky. When researching low culture and literature, these authors focused on the issue of a literary work and its author-creator as perceived in the social context. They talked about dynamics, 
evolution, development and exchangeability of literary phenomena as well as the systemic and the functional nature of culture complexes. Of import also is the formalists' thought about cinema and their theory of film aesthetics. The article pinpoints as well the theoretical achievements of Yuri Lotman, a semiotician and culturologist, who - inspired by formalist thought - expanded considerably the description and the explanation of the phenomenon mass culture, including, among others, the notion of the theory of information. Lotman's model of a literary system covers the semiotics of cultural phenomena, including the border and non-systemic features that gradually displace the elements of the official culture. Finally, the article also touches upon axiological evaluations of mass culture.

Słowa kluczowe: kultura masowa, formaliści rosyjscy, ewolucja literatury, semiotyka kina Keywords: mass culture, russian formalists, evolution of literature, film semiotics

\section{Prolegomena do pojęcia kultury masowej/literatury masowej w teoriach formalistów rosyjskich}

Kwestie dotyczące tego, co twierdzili zwolennicy metody formalnej o kulturze masowej, jakie wyznaczniki ich teorii i koncepcji badań literackich przybliżały ich do współczesnych wyznaczników pojmowania kultury i literatury masowej, jej funkcji i znaczenia w społeczeństwie zglobalizowanym, jakie miejsce zajmował ten problem w ich myśleniu o literaturze - będą głównymi założeniami pierwszej części mych rozważań.

Lata dwudzieste XX w. w dziejach kultury rosyjskiej są tym momentem, gdzie po raz pierwszy w sposób bardziej programowy zaczęto mówić o literaturze masowej i dostrzegać jej istnienie, co więcej, również znaczenie w rozwoju kulturowym, a także jakąś niepoślednią rolę w ogólnym procesie historycznoliterackim. Stało się to między innymi za sprawą teoretyków formalizmu, głównie Borysa Eichenbauma, Jurija Tynianowa i Wiktora Szkłowskiego. To, że właśnie szkoła formalizmu rosyjskiego zajęła się tym zagadnieniem, oczywiście w określonych proporcjach do podstawowego nurtu swych założeń metodologicznych, nie powinno dziwić, gdyż teoretycy tej orientacji zwracali uwagę na literaturę i jej bliskie konteksty, w tym również na sferę społeczna, czyli, jak pisali w swych pracach, życie. Można zatem powiedzieć, że teorie formalistów stanowiły w przestrzeni rosyjskiej antecedencje mowy o kulturze masowej, że wprowadzili oni do dyskusji na temat literatury i szerzej kultury - ponieważ w ich przypadku dotyczyło to również dziedziny kinematografii - refleksję o kulturze masowej jako pewien rodzaj myślenia i początkowego, embrionalnego jeszcze namysłu nad kulturą/literaturą niską - masową.

Wiadomo, że zainteresowania teoretyczne formalistów, skupiających się wokół OPOJAZU (Stowarzyszenie do Badań Języka Poetyckiego - 1916), ukierunkowane przez awangardowy wówczas nurt, czyli futuryzm, proponujący nowy wariant języka, zmodyfikowany sens praktyki literackiej, autotelicznej (zorientowanej na samą siebie), stawiały sobie za cel stworzenie samodzielnej, skonkretyzowanej nauki o literaturze, 
opartej na specyficznych właściwościach materiału literackiego, opozycyjnej do ignorującej teorię nauki akademickiej, która eksploatowała, ich zdaniem, ,przestarzałe aksjomaty" estetyczne, psychologiczne oraz historyczne. W tym tonie o założeniach metody formalnej pisał Eichenbaum w 1926 r. ${ }^{1}$ Ciążenie w związku z tym ku lingwistyce jako dyscyplinie naukowej, a zwłaszcza lingwistyce strukturalistycznej, rozumienie faktów sztuki słowa jako takiej, czyli podkreślanie ,,językowości doświadczenia literackiego"2 i badanie języka ,poetyckiego”, przeciwstawionego językowi ,,praktycznemu" stanowiły najważniejsze założenia ich teorii.

Jednym z pierwszych uczestników debat i teoretycznych rozmyślań nad kulturą masową był Jurij Tynianow (1894-1943), tłumacz, teoretyk, historyk literatury, krytyk i powieściopisarz ${ }^{3}$, który jak wszyscy zwolennicy metody formalnej w badaniu literatury i języka poetyckiego stanowiącego tworzywo i materię fundamentalną zmierzał do unaukowienia badań literackich i nadania im statusu systemu naukowego.

Aby wydobyć z myśli formalistów sedno rozważań na temat literatury masowej i uzmysłowić sobie ich dokonania w tym względzie, należy mieć na uwadze całość ich refleksji teoretycznej o literaturze i języku, o zasadzie konstrukcyjnej oraz ewolucji literackiej. Podobnie sprawa przedstawia się w przypadku Tynianowa, który swoje poglądy wyłożył w kilku pracach teoretycznych. Jedną z nich był wczesny szkic Problemy badań nad literatura i językiem (1923) ${ }^{4}$, gdzie w pierwszym rzędzie widział on literaturę w przestrzeni dyscyplin społecznych, a ściślej mówiąc-socjologicznych i w związku z tym uważał, że badaniom podlegają nie tylko funkcje konstrukcyjne, które tworzą fakt literacki, prowadzą następnie do badań nad wewnątrzliterackimi funkcjami poszczególnych gatunków, lecz także społeczna rola literatury w różnych okresach ${ }^{5}$. Tynianow postulował ponadto, aby odciąć się od ,prób ponownego przekształcenia nauki o literaturze i języku z systemu naukowego w dyscypliny epizodyczne i anegdotyczne". Teoria i historia literatury były wszak dla formalistów jednymi z nauk o kulturze, dlatego też ich stanowisko w rozumieniu kultury masowej należy określić jako kulturologiczne. Oczywiście Tynianow podkreślał znaczenie szkoły genewskiej, zwłaszcza dokonań Ferdynanda de Saussure'a, jego tradycji badawczej, która polegała na fundamen-

${ }^{1}$ B. Eichenbaum, Teoria metody formalnej [w:] Od formalizmu do strukturalizmu. Teoria badań literackich za granica. Antologia, wybór rozpraw, przeł. R. Łużny, wstęp, komentarze S. Skwarczyńskiej, cz. III, Kraków 1986, s. 165.

${ }^{2}$ A. Grzegorczyk, Formalizm w refleksji nad sztuka [w:] O kulturze i jej badaniu. Studia z filozofii kultury, red. K. Zamiara, Warszawa 1985, s. 117-136, tu: s. 126.

${ }^{3}$ Autor powieści historyczno-biograficznych: Küchla (1925), Śmierć Wezyr-Muchtara (1927-1929), Puszkin (1936), opowiadań: Podporucznik Kiże (1928), Woskowa persona (1931), Małoletni Wituszysznikow (1933).

${ }^{4}$ J. Tynianow, Problemy badań nad literaturq i językiem [w:] Fakt literacki, wybór E. Korpała, Warszawa 1978. Zob. prace: Проблема стихотворного языка - 1921, Архаисты и новаторы 1929.

${ }^{5}$ J. Tynianow, Problemy badań nad literaturq i językiem [w:] Fakt literacki, s. 4.

${ }^{6}$ Ibidem, s. 4. 
talnym rozróżnieniu parole i langue (norma i wypowiedzenie indywidualne, mowa i język) oraz badaniu ich powiązań i współzależności, które konceptualizowały się w zasadniczy przedmiot namysłu nad literaturą i językiem. Najważniejszym zagadnieniem istotnym dla zrozumienia poglądów formalistów na temat kultury masowej jest to, że pojmowali oni, w tym także Tynianow, dzieło literackie w otoczce społecznej, nie w izolacji, lecz przede wszystkim w dynamice i perspektywie diachronicznej oraz we wszelakich uwarunkowaniach oddziałujących nań zjawisk społecznych.

Praca Fakt literacki (1924) przyniosła rozszerzenie pola teoretycznych ujęć Tynianowa, pisał tu bowiem o gatunku, literaturze, fakcie literackim, eksponował kwestie ewolucyjności literatury. Poziom najwyższy w jego rozumieniu stanowiła poezja, poziom średni - literatura, najniższy zaś - piśmiennictwo. Teoretyk zalecał traktowanie i opisywanie literatury właśnie przez ,fakt literacki’, jaki jest istotą i ontologiczną definicją literatury, najważniejszą determinantą jej natury. Fakt literacki, można tak to ująć, jest zatem dla Tynianowa tym, „co zyskuje status literatury”, mówiąc inaczej, staje sięnim, jak to miało miejsce w przypadku na przykład almanachów. Fundamentalny element jego teorii literatury wyraża się poprzez pojęcie dynamizmu zjawisk literackich, wynikające z ich istnienia w płaszczyźnie społecznej. Stąd wyłaniała się ciągła dynamika, przemieszczanie i ustawiczna zmiana układu w systemie. A zatem system dynamiczny określał świadomość teoretyczną Tynianowa, który odwoływał się do pojęć centrum i peryferii, mówił o terenach pogranicznych literatury, która ma płynne granice, a więc jawi się jako system niestały i dynamiczny. Pisał tak:

Nie jest przy tym tak, że w centrum literatury zmienia się i ewoluuje jeden, odwieczny, dziedziczny nurt, a tylko z boku napływają zupełnie nowe zjawiska; nie te, te zupełnie nowe zjawiska zajmują właśnie samo centrum, a to, co znajdowało się w nim dotąd, przesuwa się na peryferie ${ }^{7}$.

Podobnie rzecz dzieje się z gatunkiem u Tynianowa, również traktowanym jako system dynamiczny, przemieszczający się, a w kolejnych epokach zachowujący swe „drugoplanowe” cechy gatunkowe. Istotą gatunku jest właśnie owa „wymiana”, innymi słowy polega to na tym, że nowe zjawisko zastępuje stare, zajmuje jego miejsce, „nie będąc bynajmniej rozwinięciem «starego»" formacji, a więc restrukturalizacji systemu,

[...] ulegając rozkładowi gatunek przemieszcza się z centrum na peryferie, a na jego miejsce z literatury błahej, z jej opłotków i nizin, przedostaje się do centrum nowe zjawisko (jest to proces „kanonizowania” młodszych gatunków). Powieść awanturnicza na przykład stała się w przeciaggu czasu gatunkiem bulwarowym - utrzymywał badacz a obecnie staje się nim powieść psychologiczna9 .

\footnotetext{
${ }^{7}$ Ibidem, s. 20.

${ }^{8}$ Ibidem, s. 19.

${ }^{9}$ Ibidem, s. 20.
} 
Ewolucja literacka w całej swej złożoności jawiła się zatem dla Tynianowa jako system dynamiczny, co ważne, jako konstrukcja językowa i układ ewoluujący, niejako „samoczynnie” i „samoistnie”, automatyzujący się i pobudzający do życia nową zasadę konstrukcyjną. Ewolucja oznaczała więc w pojęciu Tynianowa ciągłą walkę opozycyjnych zasad konstrukcyjnych, ich zmianę oraz nieustającą powtarzalność tego procesu. „Nowy prąd, nowa zmiana nie pojawia się nagle, wyskakując jak Atena z głowy Zeusa" "10, twierdził Tynianow. Zarysowuje się przede wszystkim przeciwstawna zasada konstrukcyjna, na podstawie „przypadkowych” rezultatów i „,przypadkowego” wypadnięcia z systemu, pomyłka, która się utrwala i ulega automatyzacji. Podkreślmy, że przypadkowość, drugorzędność i peryferyjność wytyczają w koncepcji Tynianowa podstawowe kryteria myślenia o literaturze masowej. Tynianow podaje tutaj przykład listu, który będąc gatunkiem życia codziennego, mając status dokumentu, a więc faktu życia, przeszedł w XVIII w. do sfery literatury i zyskał rangę faktu literackiego, odwrotnie natomiast było $\mathrm{z}$ odą, która jako gatunek dominujący zaczęła tracić znaczenie i swą czołową pozycję, innymi słowy „zużyła się literacko" ", w wyniku czego przesunęła się do poziomu wierszy szynelowych, czyli do dziedziny życia codziennego. W tym miejscu swych rozważań Tynianow przywołuje pewne zjawiska kultury masowej, czyli zmianę zasady konstrukcyjnej, jaka polega na zastępowaniu starych zasad, a więc podobnie jak to było w epoce Karamzina, na wypieraniu kategorii podniosłości przez emocje niskie, zastępowania materiału literackiego przez dotychczasowy materiał pozaliteracki i pozasystemowy. W systemie gatunkowym proces ten znalazł odzwierciedlenie w nobilitacji gatunków niskich, czyli pieśni, romansu, błahostki, przekształcających się na skutek tej wymiany w ważne zjawisko literackie ${ }^{12}$. A zatem Tynianow, jako jeden z pierwszych badaczy, opisał tutaj samoczynny mechanizm wkraczania sfery niskiej, do tej pory nieuznawanej za znaczącą, do obszarów kultury wysokiej, a zarazem wskazał na proces umasowienia literatury, transmitowania pierwiastków niskich do elitarnego kanonu literackiego.

Ciekawą konstatacją wydaje się w teorii Tynianowa dostrzeżenie imperializmu zasady konstrukcyjnej, która zagarnia coraz szersze terytoria i wkracza do sfer wysokich, czego przykładem może być czasopismo, a więc znów fakt z życia codziennego, przetransponowany w obszar literatury. $Z$ drugiej jednak strony ma miejsce, utrzymywał autor, w poszczególnych epokach literackich immanentne rozsadzanie granic literatury i ,zagarnianie terenów życia”"13, czyli proces wręcz odwrotny, kiedy to sama literatura „wyprawia się" na nowe terytoria i je zawłaszcza.

W rozwoju ewolucyjnym, nieustannej zamianie i zmianie Tynianow podkreśla, jak widać, kwestie ponownego wykorzystania dawnych zjawisk, gatunków, chwytów,

\footnotetext{
${ }^{10}$ Ibidem, s. 29.

${ }^{11}$ J. Tynianow, O ewolucji literackiej [w:] Fakt literacki, przeł. A. Pomorski, s. 46.

${ }^{12}$ J. Tynianow, Problemy badań nad literatura i językiem [w:] Fakt literacki, s. 34.

${ }^{13}$ Ibidem, s. 41.
} 
ogólnie mówiąc tego, co stare, czyli podnosi znaczenie cech kultury/literatury masowej, tzn. jej żywotne tendencje do odnawialności, wydawałoby się, już przebrzmiałych, epizodycznych i marginalnych zjawisk literackich. Istotna staje się w jego rozmyślaniach teoretycznych, podobnie jak u innych formalistów, świadomość gatunków niskich i literatury funkcjonującej poza obiegiem głównego procesu historycznoliterackiego. Materiał tej niskiej literatury ujmowany był przez Tynianowa jako płaszczyzna zapożyczeń i kontaktów z literaturą wysoką poprzez rewolucję wewnętrzną i rozsadzanie samej literatury od wewnątrz. Przytoczę taki fragment, ukazujący swego rodzaju podziw krytyka dla odwagi zwracania się niektórych autorów ku sferom pospolitym, obrazom i językowi potoczności:

Współczesna proza rosyjska popada w przesadę dwojakiego rodzaju: obawia się prostej frazy i unika jak ognia w pełni uzasadnionej niedbałości żywego języka. Tymczasem Pisiemski pisał bez obaw: „Zionący stamtąd zapach machorki jakiegoś skisłego kapuśniaku czynił życie w owym miejscu niemal nie do zniesienia"14.

W szkicu O ewolucji literackiej (1927) Tynianow, kontynuując dyskurs ewolucyjności literatury i „,szeregu literackiego”, wyraziściej poruszył kwestie literatury masowej, chociaż oczywiście nie stawiał tego zagadnienia jako pierwszoplanowego. Zastanawiał się jednocześnie nad metodami badania literatury masowej, co pozwala uznać go za jednego z prekursorów metarefleksji nad literaturą masową. Był on bowiem wyznawcą poglądu, że badania te pojawiły się jako wyraz „ślepego oporu” wobec psychologizujących metod badawczych, jak też metod opartych na teorii wartości, sprowadzających historię literatury do czegoś, jak twierdził, w rodzaju „historii wielkich jednostek" (dzisiaj powiedzielibyśmy metanarracji). A rodzące się dopiero programowe badania nad literaturą masową wyrażały właśnie wyraz sprzeciwu wobec tego rodzaju metod badawczych. Jednak brakowało, jego zdaniem, sprecyzowanej metody oglądu literatury masowej, jak też nie określono w ogóle ich znaczenia ${ }^{15}$. Istotą jego teorii było więc wartościowanie. Pojęcie „literatura masowa” miało w przekonaniu Tynianowa konotację wartościująca, podobnie jak wartościujące były pojęcia „epigonizm” czy „dyletantyzm”. Tynianow, odrzucając wartościowanie, nawoływał do zerwania $\mathrm{z}$,teoriami naiwnie wartościującymi” w badaniach nad ewolucją bądź zmiennością literatury, ponieważ wartościowanie było, jego zdaniem, zarozumiałością i zostało odziedziczone po starej historii literatury. Zauważmy zatem, że badacz, odżegnując się od wartościowania, de facto powinien uznać literaturę masową oraz jej badanie. Przytoczę dla ilustracji tej kwestii taki oto fragment:

Analiza literatury masowej dwudziestych i trzydziestych lat XIX wieku budzi przekonanie o jej kolosalnej ewolucji i zróżnicowaniu. W latach trzydziestych, latach automatyzacji

\footnotetext{
${ }^{14}$ Ibidem, s. 42.

${ }^{15}$ J. Tynianow, O ewolucji literackiej [w:] Fakt literacki, s. 46.
} 
uprzednich tradycji, latach pracy nad spożytkowaniem zleżałego materiału literackiego, „dyletantyzm” zyskuje niespodziewanie olbrzymie znaczenie ewolucyjne. Właśnie z atmosfery dyletantyzmu, z atmosfery „rymowanych notatek na marginesach książek”, wywodzi się całkiem nowe zjawisko - Tiutczew, który dzięki intymnym intonacjom przekształcił język i gatunki literackie. Żywy stosunek do literatury, z punktu widzenia ferującego oceny poczytywany za rozkład, przekształca system literacki. W latach dwudziestych, latach „mistrzów”, latach formowania się nowych gatunków w poezji, „dyletantyzm” i „literaturę masową” ochrzczono „grafomanią”. Podczas gdy „pierwszoplanowi” [...] poeci lat trzydziestych w walce z uprzednimi normami pojawiali się w kontekście ,dyletantyzmu” (Tiutczew, Poleżajew), „epigonizmu i terminatorstwa” (Lermontow), w epoce lat dwudziestych nawet ,drugoplanowi” poeci chadzali w szatach pierwszorzędnych mistrzów, np. Walerian Olin ${ }^{16}$.

Godzi się podkreślić w tym miejscu, że terminu „kultura masowa” użył Dwight Macdonald w roku 1944 (a więc dużo później niż teoretyk rosyjski) w pracy Theory of Popular Culture, określając tę kulturę jako kulturę „huby” i „raka” pasożytująca na ciele kultury wysokiej ${ }^{17}$.

Jak widać, zasada ewolucjonizmu zjawisk literackich, jak uważał Tynianow, przewartościowuje owe zjawiska i fakty, miesza ze sobą szeregi, literatury i życia, a nawet powoduje proces wymiany, w tym także literatury masowej z wysoką. Ważny w jego koncepcji jest kolejny aspekt refleksji, orientujący badacza na współczesne oceny literatury masowej, czyli zwrócenie uwagi na czytelnika, który niejako wyznacza odbiór dzieła literackiego, bowiem prowokuje wewnętrzne nastawienie narracji wypowiadawczej na siebie. „Kiedy literatura boryka się z trudnościami, zaczynamy mówić o czytelniku", twierdził w szkicu Okres przejściowy $(1924)^{18}$. Konsekwencją pojawienia się perspektywy czytelnika staje się zatem łączenie planów ,wysokiego i niskiego", a przykłady tego nowego zjawiska, czyli zderzenia niskiego z wysokim, małe, kameralne emocje Tynianow dostrzegał w poezji Dzierżawina, Jesienina, który uosabiał „,bezpośredniość osobowości twórczej”(,poszukującego pięknej oprawy dla nagiej emocji”, zanurzonego w „banalność”, „prymitywną siłę emocjonalną”), ponadto - w poezji Achmatowej, Majakowskiego, Pasternaka, Mandelsztama ${ }^{19}$.

Uznanie za oczywistą zasady rozwoju literackiego i ewolucji literackiej jako dialektycznej zmiany, samo wprowadzenie kategorii ewolucji do rozważań prowadziło zwolenników formalizmu do wniosków o nieuchronnych przewrotach w literaturze, a w konsekwencji do zajmowania się szeregami kulturowymi, które mają charakter systemowy i funkcjonalny. Zaakcentujmy, że w centrum ich uwagi znajdowały się ponadto sfery życia, ,szereg życiowy”, w związku z czym włączali oni materiał literacko-

\footnotetext{
${ }^{16} \mathrm{Ibidem}$, s. 64. Walerian Olin (1790-1839), rosyjski poeta romantyczny związany z petersburskim kołem „lubomudrów”.

${ }^{17}$ D. Macdonald, Teoria kultury masowej [w:] Kultura masowa, red. Cz. Miłosz, Kraków 2002.

${ }^{18}$ J. Tynianow, Okres przejściowy [w:] Fakt literacki, s. 137.

${ }^{19}$ Ibidem, s. 148.
} 
-życiowy do przestrzeni literatury. Borys Eichenbaum w pracy Życie literackie (1927) zwracał uwagę na inne jeszcze aspekty literatury masowej, mianowicie na kwestię samej profesji literata w nowej sytuacji społecznej porewolucyjnej Rosji, a także w nowym systemie ekonomicznym, gdy pojawiło się nowe młode pokolenie literatów i „zmieniła się sama sytuacja literatury”. Pytanie ,jak pisać?" zostało wówczas zamienione pytaniem ,jak być pisarzem?”, podkreślał autor. Dostrzegał zatem mocno zagadnienie pisarza, eksponował rolę czynników pozaliterackich i uwarunkowań społecznych i politycznych, zaś pisarza nazywał ,rzemieślnikiem pracującym na zamówienie lub wykonującym pracę najemną", a jednocześnie na skutek nowych warunków zmuszonym do tego, aby „stał się profesjonalistą w większym stopniu, niż było to konieczne przedtem”20.

„Pojawił się typ pisarza - zawodowo tworzącego dyletanta, który nie zastanawiając się nad istotą zagadnienia i nad swoim losem twórcy, odpowiada na zamówienie chałturą"21, pisał Eichenbaum. Jednocześnie, zgodnie z koncepcjami formalistycznymi, wydobywał płaszczyznę życia i czynniki ekonomiczno-społeczne, podkreślał ogólną profesjonalizację pracy literackiej, odwołując się jednak nie do współczesnej mu rzeczywistości, ale do epoki puszkinowskiej lat trzydziestych (znamienne!), w jakiej nie brakowało przejawów komercji, komercyjnego charakteru rozwoju piśmiennictwa, swego rodzaju „,przemysłu” w twórczości literackiej. Jakkolwiek by nie rozświetlać tej myśli Eichenbauma, wyraźnie odciska się tutaj już późniejsze dwudziestowieczne patrzenie na kulturę masową, gdy łączy się jej rozwój z rozwojem ekonomicznym, dostrzega związek między rozwojem ekonomicznym i kulturą, rozpatruje się sposób wytwarzania i przekazywania treści kultury, ją samą natomiast pojmuje jako produkt lub towar, wytwarzany za pomocą wyspecjalizowanych instytucji i rozprowadzany przez wyspecjalizowany system dystrybucji ${ }^{22}$. Eichenbaum podobnie wspominał o ,produkcji”, przemyśle, rzemiośle, rynku, handlu, komercjalizacji wytworów literatury, pisarstwie jako zawodzie, pisząc o nowym znaczeniu czasopiśmiennictwa w epoce lat trzydziestych XIX w., o „kierunku komercyjnym” w literaturze. Problem ów widział tak:

To wykorzystanie nowych warunków literacko-życiowych, które nie istniały poprzednio: rozszerzenie rzeszy czytelników poza granice dworskiego i arystokratycznego kręgu, pojawienie się jednocześnie z księgarzami oddzielnych zawodowych wydawców (jak Aleksander Filippowicz Smirdin), przejście od almanachów, odznaczających się charakterem ,amatorskim” do periodycznych wydań typu komercyjnego („Biblioteka dla cztienija” Sękowskiego) itd. W związku z tym znaczenie historycznoliterackie ma zapalczywa polemika i wokół zagadnienia zawodu pisarza, i ,handlowego kierunku naszego nowego piśmiennictwa”. [...] Jeszcze w 1926 r. otrzymywanie honorarium za drukowanie w czasopismach należało do rzadkości. Bułharyn, dowiedziawszy się, że redaktor czasopisma „Moskowskij Wiertnik”, Pogodin,

${ }^{20}$ B. Eichenbaum, Życie literackie, przeł. E. Socha [w:] Teoria badań literackich za granica, s. 202.

${ }^{21}$ Ibidem.

${ }^{22}$ A. Kłoskowska, Kultura masowa. Krytyka i obrona, wyd. 2, Warszawa 1980, s. 101. 
ma wypłacać honoraria, tak pisał do niego: „Oświadczenie Pańskie, że będzie Pan płacił po sto rubli za arkusz, jest nie do spełnienia”. Puszkin trafnie charakteryzuje zmianę, jaka zaszła w sytuacji literatury i pisarza, kiedy w 1836 r. pisze do Baranta (baron de Barant - historyk i polityk, pisarz): „Literatura u nas stała się ważną gałęzią przemysłu dopiero od około dwudziestu lat. Do tej pory uważano ją za zajęcie eleganckie i arystokratyczne..."’23.

Bezsprzecznie pobrzmiewa w tych wypowiedziach dzisiejszy wydźwięk pojmowania literatury jako źródła pracy i zarobku.

Pisarstwo, które stało się zawodem, deklasuje pisarza, ale stawia go w zależności od konsumenta, od zleceniodawcy. Rozwija się czasopiśmiennictwo i jego drobne formy [...], eksponowane miejsce zajmuje felieton, klasyczne poważne gatunki tracą na znaczeniu²4.

Nieuchronny rozwój literatury, który doprowadził do kontaktu z materiałem literacko-życiowym, w mniemaniu Eichenbauma, nie może jednak przywieść do „nędznej publicystyki stosowanej”, „przekładalnictwa” i „odwieść od literatury”, która powinna być nauką i nie zatracać swej „literackości”.

Idea dynamizmu i przemienialności szkół literackich nieobca była również Wiktorowi Szkłowskiemu w pracy Teoria prozy (1929), gdzie w szkicu Literatura poza tematem (Литература вне «сюжета» - 1921, 1929) 25 głosił pogląd o „przerywanym”, łamanym rozwoju procesu historycznoliterackiego, o „starszej” i „młodszej” linii literatury, gdzie dziedziczenie odbywa się według zasady: ,z wujka na bratanka/siostrzeńca” (a nie z ojca na syna). W procesie ewolucji „starsza” linia literatury staje się bezpłodna, wycofuje się i ponosi estetyczną porażkę (chociaż nie zanika i może znów wypłynąć jak „pretendent do tronu”). Szkłowski użył tu więc metafory góry lodowej, definiując starą literaturę, która opada w dół i ustępuje swe miejsce, a młodsza wznosi się do góry ${ }^{26}$.

Formalistyczna koncepcja literaturoznawcza, odznaczająca się historyczno-literackim charakterem, w swych pewnych konstatacjach na temat kultury/literatury masowej - wypływających głównie z założeń o ewolucji literackiej, zamienności i wymienialności zjawisk literackich, o imperializmie i wymianie gatunkowej - przybliża się, bez wątpienia, do niektórych już współczesnych ustaleń na temat kultury masowej. Mamy tutaj na myśli zwłaszcza takie wyznaczniki, jak, po pierwsze, zależności społeczne i ekonomiczne w rozwoju kultury, po drugie, proces demokratyzacji kultury i literatury oraz zwiększanie jej dostępności (formaliści zauważali pewne przejawy kultury masowej w okresach wcześniejszych, w wieku XVIII i XIX, kiedy to literatura

${ }^{23}$ Ibidem, s. 206-207.

${ }^{24}$ Ibidem, s. 208.

${ }^{25}$ В. Шкловский, Литература вне «сюжета» [w:] Теория прозы, 1929, www.opojaz.ru/shklovsky/vne_sujetz.html(dostęp: 5.10.2014).

${ }^{26}$ Przykładem może być Dostojewski, który wprowadził do normy literackiej chwyty powieści bulwarowej, albo Błok, który kanonizował „,romans cygański”. „Każda nowa szkoła literacka - to rewolucja, coś w rodzaju pojawienia się nowej klasy”, pisał Szkłowski. Ibidem. 
stawała się masowa poprzez jej rozpowszechnianie, a szczególnie poprzez zacieśnianie relacji z życiem). Po trzecie, idzie o „wciskanie się”, zawłaszczanie terenów zarezerwowanych dla kultury elitarnej przez literaturę o średnich i niekanonicznych normach literackich (transformacja statusu gatunkowego, np. listu, czasopisma czy powieści romansowej, jakie stały się faktem literackim, ale także środkami masowego komunikowania) i uzyskiwanie przez literaturę drugorzędną, „opłotkową”, czyli średnią, szerokiego publicznego zasięgu oddziaływania. Kryterium powszechności i masowości odbioru dóbr kultury stało się dzisiaj jednym z podstawowych sposobów definiowania kultury masowej. Antonina Kłoskowska wskazała na dwa takie zasadnicze kryteria; 1) kryterium ilości; 2) kryterium standaryzacji (masowa publiczność, zwielokrotnienie treści symbolicznych - powielanie, odbitki, kopie, druk, radio, telewizja, Internet) ${ }^{27}$.

Jednym z zasadniczych problemów, potwierdzającym zorientowanie teoretyków formalizmu na kulturę masową, było badanie i odkrywanie drugoplanowych przestrzeni literackich, przywoływanie poetów zapomnianych (tom poezji Русская поэзия ХІХ века, ред. Б. М. Эйхенбаум, Ю. Н. Тынянов - 1929). Wymowne w tym względzie stało się także ich aktywne zaangażowanie w kinematografię lat dwudziestych i trzydziestych; z tego powodu, że po pierwsze, film wszak stał się głównym narzędziem propagandy i środkiem do wyrażenia patosu rewolucji, po drugie, fenomen kina stanowił kolejny niezwykle ważny obszar dociekań formalistycznych z punktu widzenia logiki ewolucyjności sztuki. Jako jeden z szeregów kulturowych, według formalistów, kino łączyło się z literatura, było jej paralelą ze względu na swą mimetyczną naturę, obecność kategorii narracyjności, a co ważne, upraszczało materiał literacki i czyniło go przystępnym, czyli umasowiało i poddawało zabiegom prymitywizacji materiał literacki. Jako częste zaangażowania formalistów w problemy kinematografii należy wskazać na ich artykuły, recenzje filmowe, scenariusze: J. Tynianowa - scenarzysty ${ }^{28}$, W. Szkłowskiego, teoretyka kina ${ }^{29}$, czy B. Eichenbauma ${ }^{30}$.

${ }^{27}$ A. Kłoskowska, Kultura masowa ..., s. 98.

${ }^{28}$ Prace teoretyczne Tynianowa: Об основах кино, gdzie drobiazgowo rozpatrywał wyznaczniki filmu: kadr, gatunki, środki stylistyczne. Zob. Поэтика кино (1927). Autor scenariuszy: Шинель - 1926, СВД oparty na materiałach powstania dekabrystów - 1927 (wspólnie z J. G. Oksmanem), Podporucznik Kiże (1933). Zob. J. Tynianow, Поэтика. История литературы. Кино, Москва 1977.

${ }^{29}$ W. Szkłowski (1893-1984). Najważniejsze jego prace: Sztuka jako chwyt (1917), O meopuu nрозы (1929). Wygłaszał odczyty: „Литература и кинематограф” (Berlin 1922, Moskwa); współpracował z czasopismem „Киноискусство” (red. J. Sojfier, nr 1, 1923). Wydał książkę Literatura i kinematograf (Berlin 1922, wyd. II 1923), brał udział w tomie Чаплин. Сборник статей, Piotra Bogatyriewa, Konstantego Tierieszkowicza i W. Szkłowskiego (Berlin 1923), bardzo krytycznie przyjętym przez prasę sowiecką. Autor książki o Eisensteinie. Napisał kilkanaście scenariuszy filmowych (często jako współautor), np. Капитанская дочка (1928), Мертвый дом (1932, adaptacja Dostojewskiego, tu sam występował w roli Pietraszewskiego).

${ }^{30}$ B. Eichenbaum (1886-1959) mniej niż pozostali formaliści związany był z kinematografią. Był inicjatorem dyskusji o naturze kina w gazecie „Kino” (marzec 1926 - styczeń 1927). Praca: Проблема киностилистики (1927) w tomie: Поэтика кино. Tutaj też opublikowali swe prace Tynianow i Szkłowski. 
Zwrócić należy poza tym uwagę na taką stronę ich aktywności na niwie kultury masowej, a szczególnie literatury, że mimo zainteresowania literaturą masową, zwolennicy formalizmu występowali z pozycji umiarkowanej krytyki literatury masowej, dostrzegali bowiem nieuchronność jej istnienia w procesie historycznoliterackim. Z mniejszym stopniem krytycyzmu odnosili się natomiast do sztuki kinematograficznej, którą eksplorowali od strony literackiej i traktowali jako pokrewny literaturze język, kiedy rozważali w sztuce kinowej podobne do literackich środki stylistyczne i chwyty, styl oraz gatunki filmowe. Podkreślmy jednocześnie, że szczególnie u formalistów krytyka literatury masowej de facto wyprzedzała jej umasowienie, ponieważ rozwijała się ona na początkowym etapie rozwoju kultury masowej i rozeznawała dopiero nowe zjawiska i fakty literackie.

\section{Semiotyczne aspekty kultury/literatury masowej. Łotmanowski model systemu literackiego}

Kontynuacją zainteresowań literaturą masową i kulturą zajął się Jurij Łotman (1922-1993), przedstawiciel szkoły tartuskiej, która, podobnie jak formaliści, także czerpała z myśli językoznawczej i strukturalistycznej na temat systemu znaków. W naukowej twórczości Łotmana, wybitnego kulturologa, jednego z twórców teorii semiotycznych, wyodrębnia się dwa podstawowe nurty badawcze. Pierwszy to nurt strukturalno-semiotyczny, obejmujący badania nad teoretycznymi wyznacznikami tekstu, co można prześledzić między innymi w pracy Struktura tekstu artystycznego (Структура художественного текста - 1964) ${ }^{31}$, oraz drugi, kulturologiczny, sygnowany przez prace na temat kultury, jaka stała się w końcu lat osiemdziesiątych główną domeną badawczą tartuskiego semiotyka, a co było konsekwencjąpojmowania kultury jako systemu znakowego i zbioru tekstów i znalazło odbicie między innymi w książce Статьи по типологии культуры (t. I - 1970, t. II - 1973). W jego koncepcjach kultura traktowana była jako sekwencja znaków, swoisty układ językowy tworzący całą kulturę, czyli semiosferę z właściwymi jej mechanizmami funkcjonowania $^{32}$. Na gruncie tak rozumianej kultury można było wyodrębnić dwa jej oblicza, pierwsze, gdzie dominował obraz kultury utworzonej ze znaków zastępujących inne znaki (zasada semantyczna), oraz drugi, gdzie obraz kultury utworzony był z połączenia znaków (zasada syntagmatyczna) ${ }^{33}$. Rozważania Łotmana nad semiotyką różnych

${ }^{31}$ J. Łotman, Struktura tekstu artystycznego, przeł. A. Tanalska, Warszawa 1984; tu zob. Pojęcie tekstu, s. 74-84; tu też: Filmowe pojęcie „,planu” w tekście literackim, s. 370-375.

${ }^{32}$ Ю. Лотман, Семиосфера. Культура и взрыв. Внутри мыслящих миров. Статьи. Исследования. Заметки, Санкт-Петербург 2010.

${ }_{33}$ Zob. Б. Ф. Егоров, Жизнь и творчество Ю. М. Лотмана, Новое литературное обозрение, Москва 1999, s. 146. 
zjawisk kulturowych, pogranicznych, niesystemowych, a więc filmem (Semiotyka filmu $)^{34}$, teatrem, folklorem i innymi, potwierdzały olbrzymi wkład badacza do kulturologii i metodologii badań nad kulturą, w tym także jego pewne ustalenia dotyczące kultury i literatury masowej.

W kilku pracach, takich jak między innymi Postęp techniczny jako problem kulturologiczny (Технический прогресс как культурологическая проблема - 1983, $1988)^{35}$ Łotman, poprzez pryzmat psychologii masowej, przybliżył w zarysie kwestie postępu technicznego rozwijającego się w społeczeństwach Europy Zachodniej, poczynając od renesansu aż do połowy XVII w. Pojęcie „psychologia masowa” miało u Łotmana charakter historyczno-funkcjonalny, określało stan świadomości mas, społeczeństwa Zachodu na określonych etapach rozwoju historyczno-cywilizacyjnego w jego złożonych relacjach z postępem technicznym. Najczęściej były to relacje konfliktowe, dla szerokiego kręgu odbiorców wręcz katastroficzne, opanowane przez strach i negatywną psychologię masową, zwłaszcza spotęgowaną w epokach kryzysowych, implikujące gwałtowne zmiany świata i człowieka. Odkrycia i wynalazki (pismo, druk, akwaforta - połączyła rysunek i nakład, zegar, budowa dróg bądź udoskonalenie środków komunikacji lądowych i morskich) przeformułowały w istotny sposób świadomość i ideologiczne podstawy epoki.

Łotman zburzył jednak zdecydowanie optymistyczny obraz postępu swą koncepcją mitologizacji historii. Każda epoka tworzy swój własny mit, twierdził, a renesans w imię idei humanizmu, kreacji „Nowego człowieka”, człowieka - indywidualności, walcząc ze spadkiem średniowiecza, czyli, jak uważano, erą ciemnoty i inkwizycji, zbudował mit postępu, który przewartościowywał radykalnie świadomość i był przejęty później przez oświecenie. Ten model - mit, w mniemaniu badacza, oparty był wszelako na fałszywych założeniach, Łotman bowiem akcentował dwoistość zjawisk kulturowych i cywilizacyjnych, ambiwalencję mitu postępu: pozytywną i negatywną jego stronę, jakie zawsze mu towarzyszyły. Jednym z najważniejszych czynników aktywizujących rozwój nauki i techniki wedle Łotmana była de facto wynalazczość w sferze wojennej, broni i prochu (1480), następnie szybko postępująca sekularyzacja społeczeństwa, która zachwiała wiarę w Boga.

Szybka - w pamięci dwóch - trzech pokoleń, czyli w ciągu historycznie znikomego okresu - zmiana całego życia, społecznych, moralnych, religijnych jego podstaw i wartości zrodziła w masie ludności odczucie niepewności, utraty orientacji, wywołała strach i poczucie nadciagającego niebezpieczeństwa. Tylko tak można wyjaśnić nader interesujący dla badaczy psychologii masowej i ciągle nie do końca wyjaśniony fenomen

${ }^{34}$ J. Łotman, Semiotyka filmu, przeł. J. Faryno i T. Miczka, Warszawa 1983; tu zob. Miejsce sztuki filmowej w mechanizmie kultury, s. 27-47 (wyd. ros. Семиотика кино и проблемы киноэстетики, Таллинн 1973).

${ }^{35}$ Ю. Лотман, Технический прогресс как культурологическая проблема [w:] idem, Семиосфера. Культура и взрыв ..., s. 622-638. 
histerycznego strachu, ,pandemii strachu”, jaki owładnął Europą od końca XV do połowy XVII w. ${ }^{36}$

Rewolucyjna zmiana, czyli jak powiada Łotman „eksplozja w kulturze”, to te główne czynniki kulturotwórcze, ujmowane w negatywnym znaczeniu, odmieniające gruntownie świadomość masowa, lecz implikujące przy tym niekorzystne innowacje. Jako jeden z przykładów, które mocno podważyły mit postępu, podaje Łotman zjawisko palenia wiedźm, szeroko je opisując, a tłumaczy ów tragiczny etap w kulturze europejskiej jako efekt panicznego strachu, jaki zagościł w świadomości obywatela mas, wybitego z normalnych kolein życia, strachu przed heretykami czy religijnymi mniejszościami (kobiety również były ową mniejszościa). Palenie kobiet, także i mężczyzn, w rezultacie spowodowało spadek urodzeń, a z drugiej strony natomiast zwiększyło nakład literatury o czarownicach (słynny Młot na czarownice Sprengera i Kremera -1487$)^{37}$ czy też dało początek ruchom reformatorskim Lutra, Kalwina. Strach i zarazem wypieranie strachu, rugowanie Boga ze świata na rzecz demonomanii, wzrost zainteresowania ezoteryka, astrologią, poszukiwanie winnych, innymi słowy, ogólna dezorganizacja psychiczna zrodziła, według Łotmana, odczucia agresji, kazała powrócić kulturze do świadomości archaicznej: „Ruch naprzód może stymulować regenerację nader archaicznych modeli kulturowych i modeli świadomościowych, rodzić zarówno naukowe korzyści, jak i epidemię masowego strachu"38. Postęp techniczny, wedle Łotmana, paradoksalnie powoduje ,psychologiczny regres"39, wywołuje także „rewolucje semiotyczne” w dziedzinie językowej i komunikacyjnej.

Inne teksty Łotmana zajmujące się opisem kultury i literatury masowej to $\mathrm{Kul}$ tura masowa jako problem historyczno-literacki (Массовая культура как историко-литературная проблема - 1993), Czynniki historyczne i struktura tekstu (Исторические закономерности и структура текста). Zwrócił on w nich uwagę na kulturę masową i definiował ją w ujęciu historyczno-funkcjonalnym, i rzecz jasna, w semiotycznym aspekcie. Początków zainteresowań tą literaturą i kulturą na gruncie nauki rosyjskiej upatrywał w klasycznym literaturoznawstwie o antyromantycznej proweniencji, między innymi w pracach Aleksandra Wiesiełowskiego, Aleksandra Pypina, Siemiona Wiengierowa, którzy podjęli badania nad „,masami i życiem ludu”, ale też podkreślał wartość wkładu formalistów w dostrzeżenie w literaturze masowej „średnich literackich norm epoki” i ,rezerwuaru środków dla nowatorskich rozwiązań

${ }^{36}$ Ю. Лотман, Технический прогресс как культурологическая проблема, s. 628-630. Zob. inne artykuły kulturologiczne tego autora: Театральный язык и живопись, Куклы в системе культуры, Натюрморт в перспективе семиотики, Художественная природа русских народных картинок (o łubku) [w:] Ю. Лотман, Внутри мылслящих миров. Человек, текст, семиосфера, история, Москва 1996.

${ }^{37}$ Zob. J. Sprenger, H. Kramer, Młot na czarownice. Wersja uwspółcześniona, wyd. XXL, b.m.w., 2008.

${ }^{38}$ Ю. Лотман, Технический прогресс..., s. 632.

${ }^{39}$ Ibidem, s. 633. 
estetycznych"40. Łotman uznawał badania nad kulturą masową za palący problem socjologiczny i wiązał je z analizą sfery komunikacji społecznej. Istotne w jego myśli teoretycznej było rozróżnienie między pojęciem „kultura masowa”, które odnosił zdecydowanie do XX w. jako zjawiska specyficznie socjologicznego, a pojęciem „literatura masowa”. O ile to współczesne dwudziestowieczne pojęcie „kultura masowa" zakorzenione jest w sferze społecznej, to drugie powinno się ujmować, wedle Łotmana, jako obowiązkową antytezę „literatury wysokiej”. Wobec tego literatura masowa będzie się odznaczać dwiema cechami: 1) kryterium rozpowszechniania w sensie ilościowym, czyli cechować szerokim zakresem odbioru; 2) kryterium wartościowania, zarówno literatury wysokiej, jak i niskiej, tzn. że w określonej grupie społecznej jest ona odbierana jako zjawisko pełnocenne. W takim wypadku muszą istnieć aktywne normy, jakie by pozwalały literaturę tę oceniać jako niską (to znaczy w ogóle nieistniejącą, odrzuconą, apokryficzna), ale też winny istnieć kryteria przynależności do literatury wysokiej bądź niskiej. Jak widzimy, w wypowiedziach badacza traktuje się tekst w dwojakim aspekcie, włącza go bądź wyklucza z oficjalnego systemu literatury, czyli chodzi o definiowanie literatury masowej zdecydowanie poprzez ujęcie negatywne, a nie pozytywne ${ }^{41}$.

W tekście Массовая литература как историко-культурная проблема тоżna było przeczytać:

Pojęcie literatury masowej jest pojęciem socjologicznym. [...] Dotyczy ono nie tyle strukturyzacji w ogólnym systemie tekstów, ile jego społecznego funkcjonowania w ogólnym systemie tekstów, składających się na daną kulturę. W ten sposób pojęcie „literatura masowa” w pierwszej kolejności określa stosunek tej czy innej społeczności do określonej grupy tekstów. Ten sam utwór, np. poezja Tiutczewa, z jednego punktu widzenia, zwłaszcza puszkinowskiego, należała do literatury masowej, jednak z drugiego, np. naszego - taka nie jest. Tekst nie podlega zmianom, zmienia się jedynie jego miejsce i funkcja w ogólnym systemie ${ }^{42}$.

Łotman unaocznia nam dobitnie fakt, że w danym przypadku mamy zatem do czynienia z wartościowaniem.

Warto zwrócić uwagę na jeszcze jedno zagadnienie, poruszone przez Łotmana w tym tekście, mianowicie na samoświadomość literatury, która w określonej epoce wypracowuje znów podwójny obraz samej siebie. Pierwszy będzie obrazem oficjalnym i ukonstytuowanym w świadomości odbiorców dzięki krytyce i teorii literatury, a tę

${ }^{40}$ Ю. Лотман, Массовая литература как историко-культурная проблема [w:] Избранные стати в 3 томах, т. III, Таллинн 1993. Zob. też idem, Массовая литература как историко-культурная проблема [w:] О русской литературе. Статьи и исследования (1958-1993). История русской прозы. Теория литературы, Санкт-Петербург 1997, http://www.aptechka.holm.ru/statyi/ teoriya/lotman29.html, s. 1-8 (dostęp: 5.09.2014). Tu: s. 1-2.

${ }^{41}$ Ibidem, s. 2.

${ }^{42}$ Ibidem. 
autorefleksję badacz nazywa „legendą” albo „mitem” powielanym dla potomności. $\mathrm{Z}$ drugiej jednak strony w percepcji masowej kreuje się inny obraz literatury, pozaoficjalny, średni, uproszczony i pozbawiony niuansów - to mit przeciwstawny (odwrotny). Doskonale ilustruje to, uważał Łotman, przypadek opowieści Biedna Liza, jaka w przekazie na przykład rzemieślnika przekształciła się w ,awanturniczą narrację z moralizującym zakończeniem" ${ }^{43}$.

Owe dwa podstawowe mity o kulturze, pierwszy budowany przez teoretyków, drugi zaś konstytuowany przez świadomość masową, pozostają względem siebie w sytuacji konfliktu. Jakkolwiek są one ze sobą skonfliktowane, to jednak zarówno literatura wysoka, jak i literatura masowa składają się komplementarnie na całość procesu historycznoliterackiego. Literatura wysoka, na przykład w epoce Mikołaja Karamzina, odrzucała i ignorowała realizacje jej norm w sposób trywialny, szkolny i zbyt dosłowny; z kolei literatura masowa wykształciła normy, które naśladowały i parodiowały literaturę wysoka, lecz nie zdołały osiagnąć statusu godnego tego, by ją drukowano. Ta masowa literatura powstawała bowiem w kręgach poetów samouków, zazwyczaj pijaków, wtłoczonych w wariant sobowtóra, oficjalnego i prawdziwego poety, pisał Łotman, przy tym przytaczał egzemplifikacje owych faktów z osiemnastowiecznej literatury ateistycznej, wolnościowej, czy też literatury erotycznej, na przykład Barkowa. Inną cechą dystynktywną literatury masowej, wyróżnioną przez Łotmana, był jej silny związek z archaicznymi, tradycyjnymi formami literackimi, między innymi z folklorem, bądź literaturą cerkiewną, które stanowiły dlań źródło zapożyczeń. Te zaś funkcjonowały w niej jak ,żywe”, toteż literatura ta była - pisał badacz - właściwie „rezerwatem” wzorców „muzealnych”"44.

Łotmanowskie postrzeganie literatury masowej bezsprzecznie wyrasta z niektórych założeń koncepcji formalistycznej. Model literatury dynamicznej i obdarzonej aktywnością, „zużywającej się” i automatyzującej się, a następnie odnawiającej się, ma korzenie formalistyczne. Ale model ów wychodzi jednocześnie poza zakres ustaleń formalistów, dołączając nowe pierwiastki, mianowicie aspekty teorii informacji. Łotman, pisząc o teoretycznej samoocenie literatury, zaproponował bowiem „,uniwersalny model dynamicznego systemu literackiego", wyodrębniając w nim dwa produktywne etapy: pierwszy, czyli budowanie nowego systemu komunikacji artystycznej, i drugi, polegający na hamowaniu procesu rozwoju (określa go wprost jako hamulec). Właśnie na tym etapie dostrzegał pojawienie się literatury masowej, nazywając ją imitatorem i krytykiem obowiązujących dogmatów i norm literackich ${ }^{45}$.

Przechodząc na kolejny etap rozwojowy, dominująca literatura i teoria literatury jest odrzucona, przy czym nowy system teoretyczny nie powstaje w porządku ewo-

${ }^{43}$ Ibidem, s. 4. Zob. też M. A. Черняк, Массовая литература ХХ века. Учебное пособие, Москва 2009. Tu zob. Массовая литература в условиях индустриального общества, s. 5-22.

${ }^{44}$ Ю. Лотман, Массовая литература как историко-культурная проблема, s. 3-5.

${ }^{45}$ Ibidem, s. 6. 
lucyjnym, lecz budowany jest od nowa i opiera się na nowych podstawach. Mówiąc inaczej, mechanizm nakreślony tutaj polega na zmienności; to, co stare, odchodzi, a powstaje nowe i tworzy się w oparciu o zupełnie nowe zasady, czyli mamy do czynienia - można by rzec, rozwijając myśl Łotmana - z czymś w rodzaju dekonstrukcji starego systemu. Elementy niesystemowe, ,przypadkowe” i „zbędne” składają się na materiał dla nowego systemu, stając się „rezerwą” dla nowej struktury, czyli „,̇ywą literaturą", twierdził badacz. Podobnie jak formaliści eksponował on językowy typ struktury literackiej, lecz język traktował jako organizatora ,informacji”.

Zasługą Łotmana było również podkreślenie podobieństw między literaturą masową i folklorem ze względu na zbliżone zasady konstrukcyjne (stabilność języka artystycznego, poetyka dobrego zakończenia), co w dzisiejszych opracowaniach na temat literatury masowej jest szczególnie podnoszone. Cechą literatury masowej, uważał, jest wyznacznik tekstu zakończonego, zawsze pozytywnie, co winno spełniać funkcję kompensującą (wedle reguły i opozycji: złe życie, dobra literatura), tym bardziej że mamy do czynienia ze strukturą o nieskomplikowanym charakterze. Czytelnik bowiem pragnie otrzymać informację z zewnątrz, typową dla komunikacji w języku naturalnym, pisał Łotman. Toteż kategoria końca, pytanie ,jak to się skończyło?”, na przykład w powieści XIX w., odgrywa dla sytuacji narracyjnej wielką rolę modelującą: „Именно она приводит к сосредоточению информации в тексте и вычленению текста из контекста как автономного понятия"46. Happy end spełnia także funkcję zróżnicowaną pod względem poznawczym, inne wszak jest zakończenie bajki, inne - powieści bulwarowej. W ujęciu tartuskiego badacza na uwagę zasługuje jeszcze kwestia tego rodzaju, że literatura masowa powstaje w społeczeństwie o określonej i już ustabilizowanej tradycji literatury wysokiej, formując się właśnie na bazie tejże mocnej tradycji. Literatura masowa - w przekonaniu Łotmana - posiada podwójną „naturę prymitywizmu”. Służy z jednej strony jako środek burzenia kultury, z drugiej natomiast może być wciagnięta $\mathrm{w}$ jej system, uczestnicząc $\mathrm{w}$ budowaniu nowych form strukturalnych jako ich opozycja, parodia, ogólnie mówiąc, inna ich strona ${ }^{47}$.

Podsumowując rozważania, warto by jeszcze podnieść bardzo ważny aspekt obu zaprezentowanych wyżej poglądów na temat kultury/literatury masowej, mianowicie problem wartościowania, tak żywo obecny we współczesnych dyskusjach o jej wyznacznikach, roli i funkcjach społecznych. Otóż kwestia wartościowania wytworów kultury nie była przez formalistów tak zaogniona, jak to się dzieje obecnie, gdy odgrywa ona nadrzędną rolę, stając się faktycznie kryterium rozróżniania, inaczej mówiąc, separacji kultury wysokiej i kultury masowej, jaka określana jest najczęściej przez jej zagorzałych krytyków jako komercyjna ${ }^{48}$, ogłupiająca, wulgarna, prymityw-

${ }^{46}$ Ibidem, s. 7.

${ }^{47}$ Ibidem, s. 8.

${ }^{48}$ Zob. J. Ortega y Gasset, Bunt mas, Warszawa 2006; A. Bloom, Umyst zamknięty, Poznań 1997; Kultura masowa. Antologia, red. Cz. Miłosz, Kraków 1959; U. Eco, Superman w kulturze masowej [w:] Powieść popularna, Warszawa 1996. 
na, przy czym, co akcentuje wielu jej badaczy, wytwarzana jest w sposób nader profesjonalny. Inaczej zatem problem aksjologii przedstawiał się w ocenach formalistów, którzy nie ferowali zbyt surowych opinii o kulturze masowej, inaczej jeszcze u Łotmana, który - w przeciwieństwie do formalistów - kryterium wartościowania stawiał bardzo wysoko, pozwalało ono bowiem na dyferencjację obu sfer kultury, pozwalało mówić o ich antytezie czy wręcz opozycji.

\section{Literatura}

Eichenbaum B., Teoria metody formalnej [w:] Od formalizmu do strukturalizmu. Teoria badań literackich za granica. Antologia, wybór rozpraw, przeł. R. Łużny, wstęp, komentarze S. Skwarczyńskiej, cz. III, Kraków 1986.

Eichenbaum B., Życie literackie [w:] Od formalizmu do strukturalizmu. Teoria badań literackich za granica, Kraków 1986.

Grzegorczyk A., Formalizm w refleksji nad sztuka [w:] O kulturze i jej badaniu. Studia z filozofii kultury, red. K. Zamiara, Warszawa 1985.

Kłoskowska A., Kultura masowa. Krytyka i obrona, wyd. 2, Warszawa 1980.

Łotman J., Semiotyka filmu, przeł. J. Faryno i T. Miczka, Warszawa 1983.

Łotman J., Struktura tekstu artystycznego, przeł. A. Tanalska, Warszawa 1984.

Tynianow J., O ewolucji literackiej [w:] Od formalizmu do strukturalizmu. Teoria badań literackich za granica, Kraków 1986.

Tynianow J., Problemy badań nad literaturq i językiem [w:] Fakt literacki, wybór E. Korpała, Warszawa 1978.

Егоров Б., Жизнь и творчество Ю. М. Лотмана, Москва 1999.

Лотман Ю., Массовая литература как историко-культурная проблема [w:] Избранные стати в 3 томах, т. III, Таллинн 1993.

Лотман Ю., Массовая литература как историко-культурная проблема [w:] О русской литературе. Статьи и исследования (1958-1993). История русской прозы. Теория литературы, Санкт-Петербург 1997.

Лотман Ю., Технический прогресс как культурологическая проблема [w:] Ю. Лотман, Семиосфера. Культура и взрыв. Внутри мыслящих миров. Статьи. Исследования. Заметки, Санкт-Петербург 2010.

Тынианов Е., Поэтика. История литературы. Кино, Москва 1977.

Черняк М. А., Массовая литература ХХ века. Учебное пособие, Москва 2009.

Шкловский В., Литература вне «сюжета» [w:] Теория прозы, 1929, www.opojaz. ru/shklovsky/vne_sujetz.html. 